\title{
Criticality Analysis of HTR-10 using an Open Source Monte Carlo code OpenMC
}

\author{
Ikhsan Mahfudin*1, Topan Setiadipura ${ }^{2}$ \\ ${ }^{1}$ Polytechnic Institute of Nuclear Technology, Jl. Babarsari, Kotak Pos 6101 YKBB Yogyakarta, Indonesia \\ ${ }^{2}$ Center for Nuclear Reactor Technology and Safety, Gedung No.80, Kawasan Puspiptek Tangerang Selatan, Indonesia
}

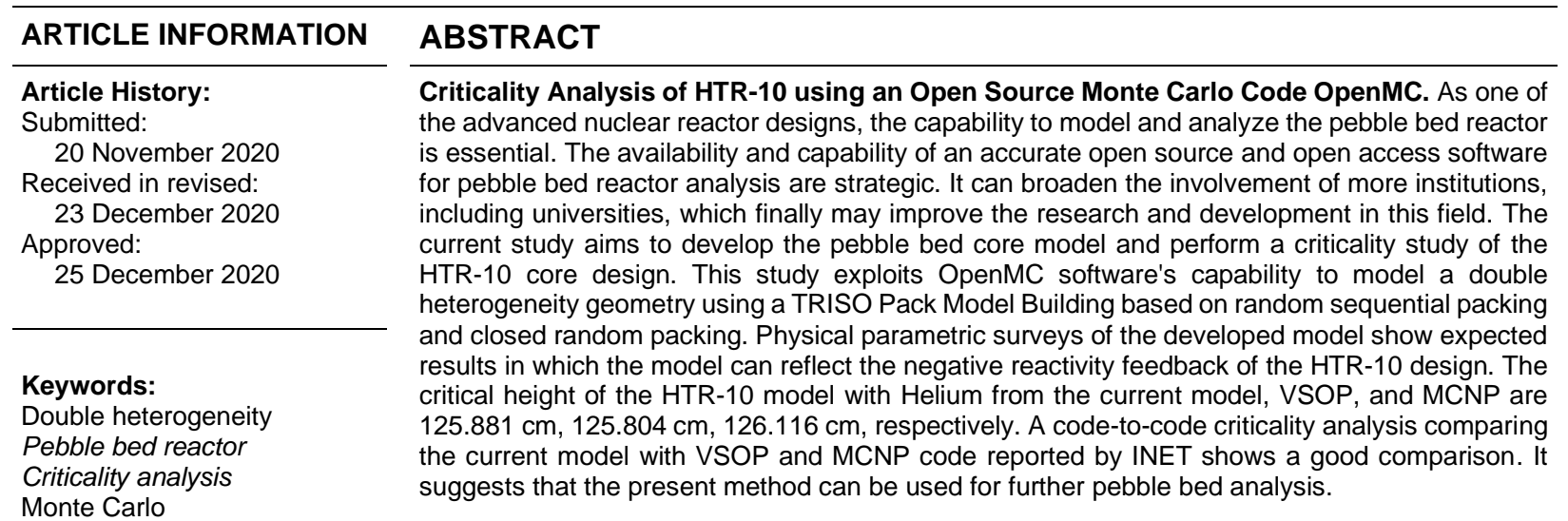

Monte Carlo

openMC

\begin{abstract}
ABSTRAK
Analisis kritikalitas HTR-10 Menggunakan Software Monte Carlo Open Source OpenMC. Sebagai salah satu desain reaktor nuklir maju, kemampuan untuk melakukan pemodelan dan analisis terhadap reaktor pebble bed adalah hal yang penting. Ketersediaan dan kemampuan dari sebuah software yang akurat, open source dan open access untuk analisis reaktor pebble bed sangatlah strategis. Hal ini dapat memperluas keterlibatan institusi, termasuk universitas, yang pada akhirnya akan meningkatkan penelitian dan pengembangan di bidang ini. Tujuan dari studi ini adalah untuk mengembangkan model teras pebble bed dan melakukan analisi kritikalitas desain HTR-10. Studi ini memanfaatkan kemampuan dalam software OpenMC untuk memodelkan geometri heterogenitas ganda menggunakan modul TRISO Pack Model Buiding berbasis random sequential packing dan closed random packing. Survey parameter fisis terhadap model yang dikembangkan dalam studi ini menunjukkan hasil yang diinginkan dimana model tersebut dapat menunjukkan fitur umpan balik negative dari reaktivitas terhadap termperatur yang merupakan fitur HTR-10. Ketinggian kritis dari model HTR-10 dengan helium dari model openMC, VSOP, dan MCNP adalah $125.881 \mathrm{~cm}, 125.804 \mathrm{~cm}$, dan $126.116 \mathrm{~cm}$, secara berurutan. Perbandingan antar software untuk analisis kritikalitas ini menunjukkan hasil yang baik dan bahwa model openMC yang dikembangkan dalam studi ini dapat digunakan untuk analisis pebble bed selanjutnya.

Kata kunci: Heterogenitas Ganda, Reaktor Pebble Bed, Analisis Kritikalitas, Metode Monte Carlo, OpenMC, HTR-10
\end{abstract}

\section{INTRODUCTION}

As one of the advanced nuclear reactor designs, with a unique random geometrical composition, the capability to model and analyze pebble-bed high-temperature reactor core is important. In addition, as a moving fuel core, detailed modeling, and method to accommodate fuel movement in the core will be needed in further equilibrium and safety analysis. Currently, there are fourteen high-

* Penulis korespondensi.

E-mail: ikhsanmahfudin@gmail.com temperature gas-cooled reactors (HTGR) designs as reported by IAEA, in which half of it is pebble bed reactor (PBR) type, being developed in the world [1]. PBR design is usually chosen due to its strong passive safety feature, its cogeneration potential, and its capability to be optimized as a small modular reactor [2]. For that reason, as part of the national development program [3], a PBR design development called Reaktor Daya 
Eksperimental was developed by the National Nuclear Energy Agency (BATAN). Equilibrium and safety analysis of RDE was performed using a finite difference based analysis with a specific method to model the fuel movement in the core [2][4]. A Monte Carlo (MC) based analysis for a Once-Through-Then-Out (OTTO) fuel refueling of PBR called MCPBR [5] is already developed. However, it cannot perform a multi-pass refueling scheme, which is applied in RDE. Design and analysis of PBR type present a unique challenge due to its random nature of the fuel and core design. This characteristic is called double heterogeneity from the TRISO random position in the pebble fuel and the pebble fuel random position in the core, as shown in Figure 1. Therefore, more accurate analysis of the Monte Carlo method is preferred to model and analyze the PBR core for criticality analysis and the equilibrium and safety analysis. In particular, to model the multipass scheme applied in RDE, some of the irradiated fuels are re-inserted to the core. An open-source code with open access and flexibility to modify and create a specific calculation flow is needed to complete PBR analysis. However, the current paper only limited to the critical analysis of PBR using an open-source MC code. Criticality analysis is traditionally used as an initial check for a particular code or method's modeling capability. HTR-10, which already got its first criticality since 2000 [4] becoming the common object to be analyzed. The initial calculation from the Institute of Nuclear Energy Technology (INET), which designed and constructed the HTR-10, was using VSOP94 code [7], a diffusion calculation code. A simplified geometry by homogenization of some zone of the fuel and core usually needed to be done in the diffusion-based code. To have a more accurate analysis, in particular, to capture the double heterogeneity of the pebble bed core, a Monte Carlo based analysis is preferable. MCNP code, with many of its versions, is the most commonly used code for the HTR-10 criticality analysis [10]. SCALE [10], and MVP [14], TRIPOLI [15] code also used for the criticality analysis of HTR-10.

In spite of many Monte Carlo based code used for the analysis of pebble bed core, most of them are not an open-source nor openaccess code. Availability of an open-source
Monte Carlo code to analyze double heterogeneity of pebble bed reactor is strategic to extend a broader institution's involvement or even the one with no institution or financial backup to acquire the licensed and proprietary software.

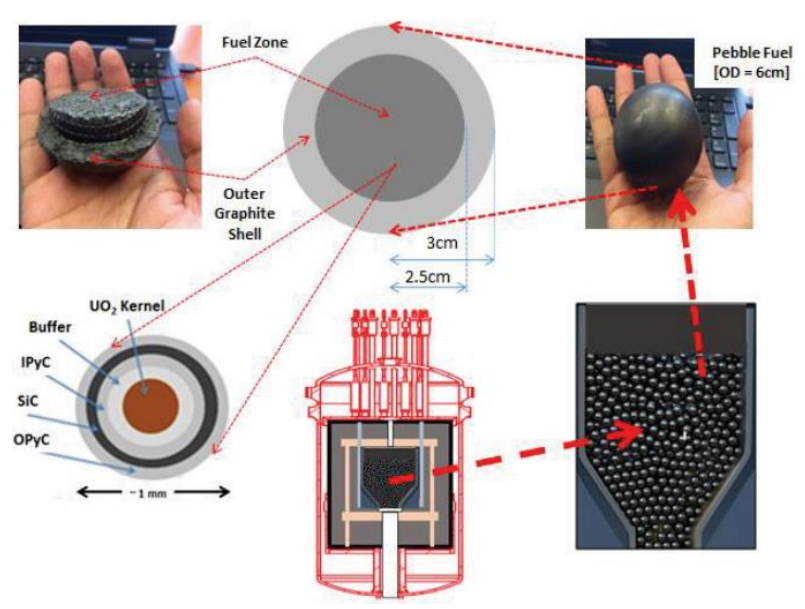

Figure 1. Pebble Bed Reactor Core Composition [[4],[6].

OpenMC Monte Carlo code [16] provides the nuclear community with such luxury that anyone can access and use it to perform an analysis for nuclear-related systems based on the Monte Carlo method. A strong and productive community spearheaded by the students and researchers from Computational Reactor Physics Group at the Massachusetts Institute of Technology add the beneficiary of mastering and applying this code. One of its interesting applications is in the analysis of the PBR, in particular, started with criticality analysis of HTR-10 [17].

The purpose of this study is to perform a criticality analysis of HTR-10 pebble bed core using an open-source code openMC. As far as our reading, no such analysis was already done using openMC. Comparison with the HTR-10 criticality results provided by the Chinese researcher using the VSOP code and MCNP code is also performed to check the current analysis's accuracy. This study is expected to be the initial step for developing PBR analysis tools for equilibrium and safety analysis based on $\mathrm{MC}$ method for a multipass fuel scheme. The opensource status of OpenMC provides flexibility to access the source code and develop the required model e.g. to accommodate the movement of the fuel. OpenMC capability to model a random geometry, which its inability in MCNP, is also an interesting aspect to compare both models' 
results. The current study is limited to criticality analysis, while many interesting topics such as the depletion analysis are possible with these powerful tools.

In the following part of this paper, the methodology in modeling the TRISO coated particle, pebble fuel, and pebble-bed core is explained. Then, results and discussion of the criticality analysis are given and ended with a conclusion.

\section{METHODS}

HTR-10 design of its core and fuel are given in Table 1 and Table 2. Initial critical core of HTR-10 was achieved experimentally with the core height of active core at $123.06 \mathrm{~cm}$ at $27^{\circ} \mathrm{C}$. The composition ratio of pebble fuel and moderator fuel in the initial critical layout is $57: 43$.

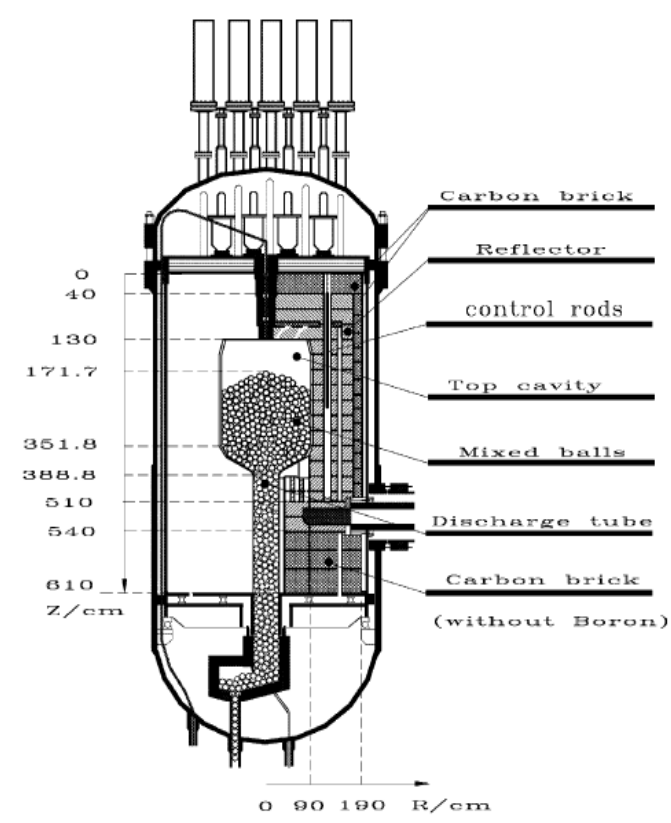

Figure 2. Initial core layout of HTR-10 [20].

Table 1. Design Characteristics of HTR-10 [20].

\begin{tabular}{cc}
\hline Parameter, Unit & Nilai \\
\hline Thermal Power, MW & 10 \\
Core diameter, cm & 180 \\
Average core height, cm & 197 \\
Primary Loop Pressure, Mpa & 3 \\
Power Density, MW/m & 2 \\
Number of control rod & 7 \\
Number of pebble fuel in the core & 27.000 \\
\hline
\end{tabular}

Table 2. Pebble Fuel and Moderator Ball Characteristics of HTR-10 [4].

\begin{tabular}{cc}
\hline Parameter, Unit & Nilai \\
\hline Pebble fuel diameter, cm & 6 \\
Graphite shell thickness, cm & 0,5 \\
Uranium loading per pebble, gr & 5 \\
Number of TRISO particle per & 8335 \\
pebble & 17 \\
U-235 encrichment, \% & 10,4 \\
$\mathrm{UO}_{2}$ Density,g/cm ${ }^{3}$ & 0,025 \\
Diameter of fuel kernel, cm & $\mathrm{PyC} / \mathrm{PyC} / \mathrm{SiC} / \mathrm{PyC}$ \\
Coating layers material & 04 \\
Thickness of coating layers, cm & $0,009 / 0,004 / 0,0035 / 0,0$ \\
Density of coating layers, g/cm & $1,1 / 1,9 / 3,18 / 1,9$ \\
Boron impurity in graphite, ppm & 1,3 \\
Boron impurity in kernel, ppm & 4 \\
Density of graphite in moderator & 1,73 \\
pebble, g/cm ${ }^{3}$ & \\
\hline
\end{tabular}

OpenMC have a specific feature to model the TRISO fuel called TRISO Pack Model Building by calling the openmc.model.pack_trisos[18]. The particle configuration resulted from this module is generated by a combination of random sequential packing (RSP) dan closed random packing (CRP). For a packing factor more than $\sim 0.38$, which reflect most of pebble bed core design, the CRP method is chosen[19]. This feature is utilized in current model development of HTR-10 core starting from its TRISO coated particle, pebble fuel, and pebble bed core. In performing the neutron transport simulation, OpenMC utilized advanced methods such as the Wielandt method for source convergence. As with other Monte Carlo based code, openMC used a cross-section library in the form of a compact ENDF (ACE) file. Current research is performed using OpenMC version 0.7.0. for the main executable based on the Windows platform. It is combined with the 0.10 .0 version for the graphical output of the model. ENDF/BVII is used in this study, and temperature at 293 $\mathrm{K}$ except mention explicitly for the temperature reactivity feedback case. The criticality analysis is performed using a 200 active cycle with an earlier 50 inactive cycle and 10000 neutrons in each cycle. To account for the effects of chemical binding and crystalline for the thermal neutron scattering kinematics, an 
$S(a, \beta)$ correction is applied for graphite material.

\subsection{Tristructural-isotropic (TRISO) Coated Particle}

The first step of the geometrical model development is to model the TRISO coated fuel particle. As mentioned in Table 2, it comprises file layers with different material compositions. The most inner part is the uranium oxide $\left(\mathrm{UO}_{2}\right)$ kernel. It is the main nuclear fuel that provides the chain fission reaction. Then, a low-density pyrolytic carbide called buffer layer. This layer is important to accommodate the fission product particle from the kernel to reduce the internal pressure. Then, added with an Inner Pyrolytic Carbide (IPyC) and Outer Pyrolitic Carbide (OPyC), which provide mechanical support to the $\mathrm{SiC}$, finally in between IPyC and OPyC there is a Silicon Carbide layer which has the highest density and plays a vital role in confine fission product. OpenMC model of the TRISO coated fuel particle is shown in Figure 3.

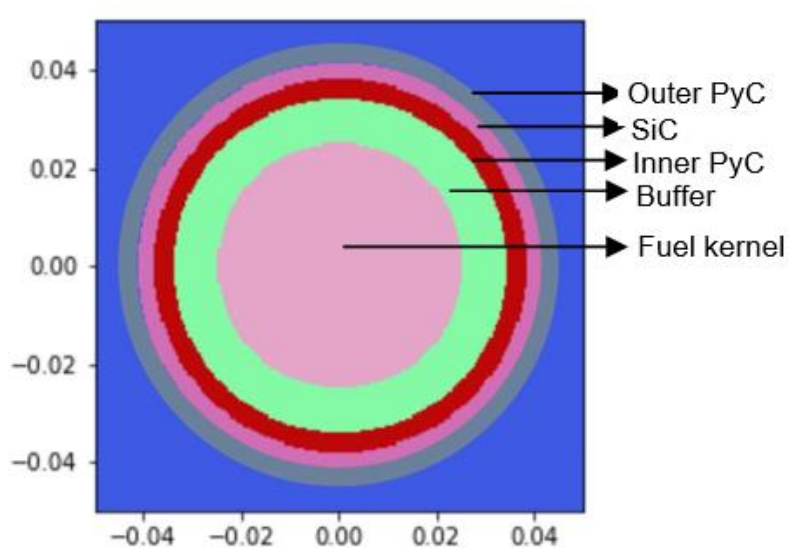

Figure 3. OpenMC Model of TRISO Coated Fuel Particle.

\subsection{Pebble Fuel}

Next is to model the pebble fuel. As mentioned in Table 2, pebble fuel is divided into regions. The outer region is the graphite shell with a thickness of $0.5 \mathrm{~cm}$, the density of this graphite is $1.73 \mathrm{~g} / \mathrm{cm}^{3}$ [4]. And the inner region, called fuel zone, is a $2.5 \mathrm{~cm}$ sphere in which 28335 TRISO coated fuel particle is dispersed randomly with a packing fraction of 0.050248 [[15]. Graphite, which becomes the inner side matrix, has the same density as the graphite in the outer shell.
Based on the geometrical parameters (particle size, packing factor) random position of thousands of TRISO coated fuel particles in the pebble fuel zone is constructed by the TRISO Pack Model Building by calling the openmc.model.pack_trisos. This module ensures that no TRISO coated fuel particle has overlap with other TRISO coated fuel particles. Simultaneously, the moderator pebble with no fuel zone is modeled by a simple sphere geometry with graphite material. OpenMC model of the pebble fuel with dispersed TRISO coated particle is shown in Figure 4.
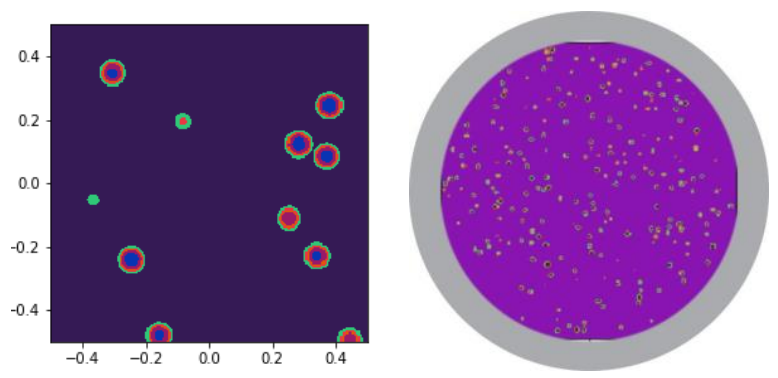

Figure 4. OpenMC Model of the HTR-10 Pebble Fuel.

\subsection{Pebble bed core}

Finally, the pebble fuel is also put randomly in the pebble bed core. OpenMC able to accommodate different particle with certain ratio to be dispersed in particular geometry (called universe as in most Monte Carlo code). The same random module is utilized in which currently there are two 'particles' to be dispersed, the pebble fuel and pebble moderator. Total packing fraction of both pebble fuel and pebble moderator is 0.61 [10], and the matrix filling the empty region is Helium. The design of the pebble bed geometry is model as given in Table 1 .

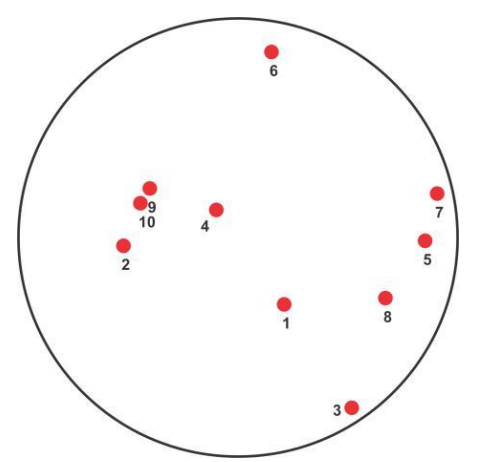

Figure 5. Sequential Pattern of Random Pebble Fuel Positioning Based on Identity Number. 
In current model, TRISO Pack Model Building perform a random positioning of the pebble fuel incrementally for certain height layer. Random composition for particular height layer is shown in Figure 5.

Based on the above positioning pattern, different fill function is assigned to simulate the pebble fuel or pebble moderator. Pebble fuel is assigned for $57 \%$ of the first id while the rest particle-ids are assigned as pebble moderator [4]. Using this strategy, we can assure that a randomly mixed composition between fuel pebble and moderator is achieved. OpenMC model of the HTR-10 with only void, active core, bottom cone, and discharge column is shown in Figure 6. The void region in the above active core is filled with Helium, while the bottom core is filled with pebble moderator. Active core height is model from $90 \mathrm{~cm}$ to $197 \mathrm{~cm}$, which is the full core layout. This active core height is performed to make a code-tocode comparison to the VSOP and MCNP results. A full core HTR-10 layout is shown in Figure 6.
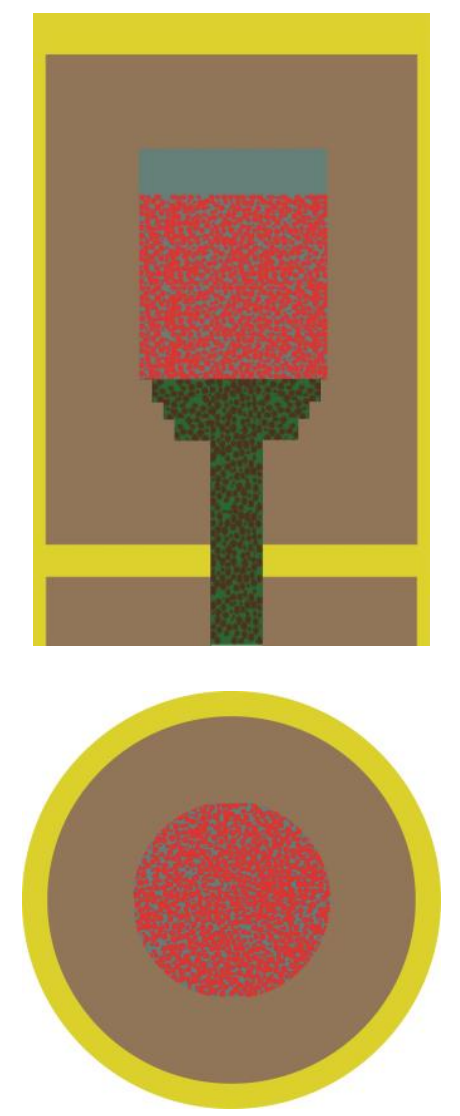

Figure 6. OpenMC Model of HTR-10 Full Core for Vertical and Horizontal View.

\section{RESULTS AND DISCUSSIONS}

For the TRISO coated fuel particle model, a simple physics test is performed. Criticality calculation is executed at temperature $293 \mathrm{~K}$ using a reflective boundary in the layer's outermost part (OPyC layer). The parametric survey is performed by varying the enrichment of the U-235 in the $\mathrm{UO}_{2}$ kernel. As expected, the calculation results show an increase of $k_{\text {inf }}$ for higher U-235 enrichment, as shown in Figure 7.

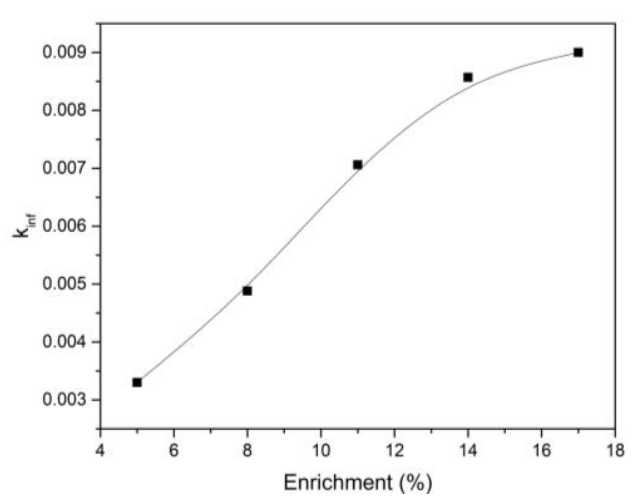

Figure 7. U-235 Parametric Survey for The TRISO Coated Particle Model in OpenMC.

For the pebble fuel model, a different physics parametric survey is performed. Using a boundary reflective at the outer part of the pebble fuel criticality calculation is performed for the 17\% U-235 enrichment for different temperatures. As expected, the multiplication

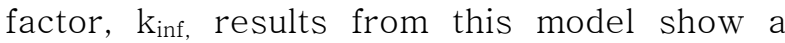
decrease for higher temperature, as shown in Figure 8. It shows the design's negative temperature reactivity feedback, which contributes to the strong passive safety feature[2][21].

For the pebble bed core model, the same temperature reactivity feedback survey is also performed. Again as physically expected, the constructed openMC pebble bed core model shows a negative temperature reactivity feedback in which the keff is decreasing for higher temperature [21], as shown in Figure 9. For both the pebble fuel and pebble bed case, the temperature given is for all the regions, not only the fuel kernel. A detailed temperature difference for each material or region is possible to be performed in openMC. However, current analysis is limited for this general case to justify that the model is correctly constructed in openMC. 


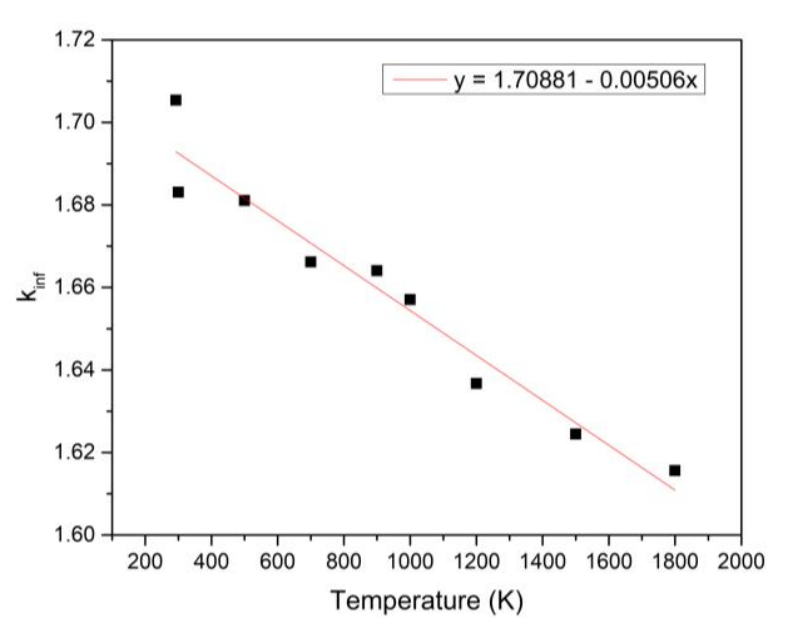

Figure 8. Temperature Parametric Survey for The Infinite Multiplication Factor of OpenMC Pebble Fuel Model.

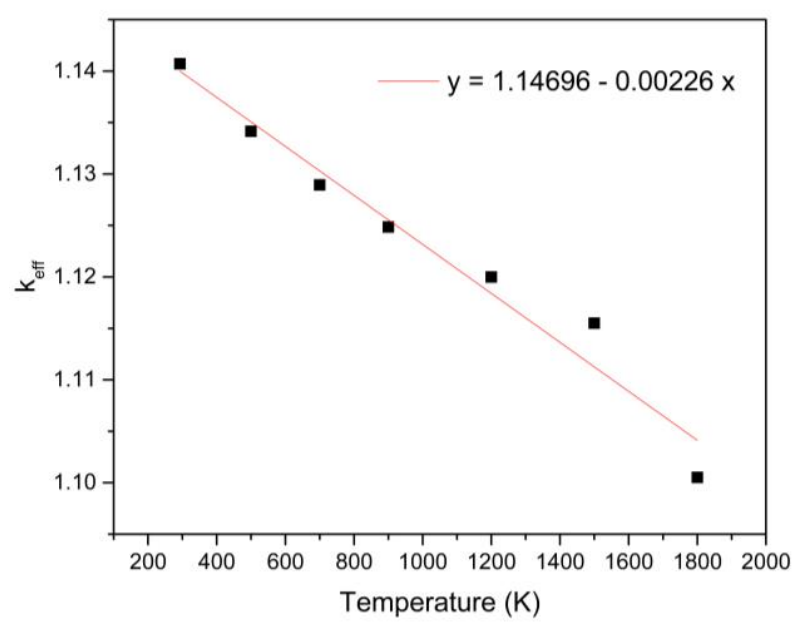

Figure 9. Temperature Parametric Survey For The Infinite Multiplication Factor Of OpenMC HTR-10 Pebble Bed Core.

Effective multiplication factors, $\mathrm{k}_{\mathrm{eff}}$, of the full core model design of HTR-10 for different active core height with helium coolant filled the empty region between the ball in Table 3 . Based on these results, the critical height of the HTR-10 resulted from the current OpenMC model with a Helium temperature of $293 \mathrm{~K}$ is $125.881 \mathrm{~cm}$. At this critical condition, the number of the total pebble in the pebble core is 17267 pebbles in which fuels and moderators are 9842 and 7425 pebbles, respectively. Meanwhile, the criticality height from the VSOP and MCNP which reported by INET is 125.804 $\mathrm{cm}$ dan $126.116 \mathrm{~cm}$, respectively. These results show a good comparison and reflect a good openMC model of HTR-10 developed in the current study.

Comparison of the current study to the results for certainly available heights to the data of VSOP and MCNP, which reported by the
INET [20] is given in Table 4. The lattice model used in the above MCNP calculation is the hexagonal lattice model [20]. The maximum difference of the current study to previous results is $0.38 \%$, which can be considered to be a good comparison. MCNPbased code actually has a method to perform a specific random geometry. However, the neutronic effect between the random model and fixed lattice is negligible[22]. Nevertheless, the above data not necessarily means that different double heterogeneity model in the current OpenMC and MCNP used by INET is negligible. In fact, current results provide initial data on this comparison. In addition, complicated modeling using the fixed lattice is prone to error in model development. Hence, a more simple random geometry definition in the OpenMC has an advantageous point.

These differences also might result from different cross-section libraries. The current study used ENDF/B-VII while the INET calculation using ENDF/B-V [20]. Comparison of MCNP calculation using ENDF/B-VII and $\mathrm{ENDF} / \mathrm{B}-\mathrm{V}$ gives a difference of $\sim 300 \mathrm{pcm}$, where $\mathrm{WNDF} / \mathrm{B}-\mathrm{VII}$ have a higher value [23]. This trend is the same for the model with Helium in the current study, but the model with air as the coolant has a different trend in which the ENDF/B-VII nuclear library in OpenMC gives a lower multiplication factor. Further study of different nuclear data library effects in the PBR model with OpenMC is needed.

Table 3. OpenMC Criticality Calculation Results of HTR10 with Helium Coolant.

\begin{tabular}{cccc}
\hline $\begin{array}{c}\text { Active Core } \\
\text { Height }(\mathrm{cm})\end{array}$ & $\begin{array}{c}\text { Number of } \\
\text { Pebble Fuel }\end{array}$ & $\begin{array}{c}\text { Number of } \\
\text { Pebble } \\
\text { Moderator }\end{array}$ & keff \\
\hline 197 & 15412 & 11588 & 1.1407 \\
186 & 14551 & 3823 & 1.12498 \\
174 & 13612 & 10269 & 1.10687 \\
162 & 12674 & 9561 & 1.09086 \\
150 & 11735 & 8853 & 1.05938 \\
140 & 10953 & 8262 & 1.04158 \\
130 & 10170 & 7673 & 1.01349 \\
120 & 9388 & 7082 & 0.98128 \\
110 & 8606 & 6492 & 0.95277 \\
100 & 7823 & 5902 & 0.91218 \\
90 & 7041 & 5312 & 0.85706 \\
\hline
\end{tabular}


Table 4. Code-to-code Comparison For Particular Active Core Height Between OpenMC, VSOP and MCNP[20].

\begin{tabular}{cccc} 
Active Core & \multicolumn{3}{c}{$k_{\text {eff }}$} \\
\cline { 2 - 4 } Height $(\mathrm{cm})$ & OpenMC & VSOP & MCNP \\
\hline 150 & 1.05938 & 1.062702 & 1.06201 \\
120 & 0.98128 & 0.982018 & 0.98148 \\
90 & 0.85706 & 0.863683 & 0.86062 \\
\hline
\end{tabular}

The calculation was also performed for the model in which the empty room between the pebble fuel is filled with air (not Helium). This is the actual initial criticality height experiment which performed in the HTR-10. The given critical height from the HTR-10 experiments is 123,06 cm. Code-to-code comparison between the results of the current study and the MCNP results reported by the INET at this particular critical height [20] is shown in Table 5. These results indicate a lower $k_{\text {eff }}$ given by the current openMC model, while both code results show a lower keff than the HTR-10 experiment. Again, one of the possible reasons for this discrepancy is the different nuclear data used in both models. However, these values show that the HTR-10 model developed in the current study is acceptable and can be used as a basis for further advanced calculations such as depletion and equilibrium calculation of the pebble bed reactor. Also, the opensource status of OpenMC code in which access to the source of the code and make a modification on it is permissible, provide a huge advantage to accommodate the movement of the pebble fuel in the core, which needed in equilibrium calculation. The status of OpenMC also provides an opportunity for more institutions, including universities, to study and developed a PBR design.

Table 5. Criticality calculation result with air at an active core height $123.06 \mathrm{~cm}$ [23].

\begin{tabular}{cc}
\hline Case & $\mathrm{k}_{\text {eff }}$ \\
\hline Experiment & $1.0131 \pm 0.000297$ \\
MCNP & $1.01190 \pm 0.00021$ \\
OpenMC & $0.99630 \pm 0.00580$ \\
\hline
\end{tabular}

\section{CONCLUSION}

HTR-10 model from the TRISO coated fuel particle, pebble fuel, and pebble-bed core is already developed using openMC in the current study. Physical parametric surveys of the model show good calculation results in which it can reflect the negative temperature reactivity feedback of the HTR-10. The critical height of the HTR-10 model with Helium from the current model, VSOP, and MCNP are $125.881 \mathrm{~cm}, \quad 125.804 \mathrm{~cm}, \quad 126.116 \mathrm{~cm}$, respectively. For model with air as in the experiment condition with core height of 123.06, results of current openMC model, MCNP, and HTR-10 experiments are $0.99630 \pm 0.00580, \quad 1.01190 \pm 0.00021$, 1.0131 \pm 0.000297 . This code-to-code comparison shows a good agreement and suggests that the current OpenMC model is acceptable and can be used for further pebble bed reactor analysis, such as depletion and equilibrium core calculation. Availability and capability of an open-source and open-access code such as OpenMC are expected to provide a basis for further development of PBR with $\mathrm{MC}$-based tools. It is expected to broaden the involvement of more institutions.

\section{Acknowledgement}

The authors highly acknowledge Dr. Geni Rina Sunaryo, M.Sc as Director of PTKRN-BATAN, and Edy Giri Rachman Putra, Ph.D. as Director of STTN-BATAN, which gave the permission for this research collaboration in July-August 2019.

\section{References}

[1]. Advances in Small Modular Reactor Technology Developments, International Atomic Energy Agency, Vienna, 2020.

[2]. T. Setiadipura, S. Bakhri, G.R. Sunaryo, D.S. Wisnubroto, "Cooling passive safety features of Reaktor Daya Eksperimental”, in AIP Conference Proceedings, 1984(1) 020034, 2018.

[3]. Presidential Decree No.2-2015: Rencana Pembangunan Jangka Menengah Nasional Tahun 2015-2019, Pemerintah Republik Indonesia, Jakarta, 2015.

[4]. T. Setiadipura, Suwoto, Zuhair, "Equilibrium Core Design of Reaktor Daya Eksperimental", Journal of Physics: Conference Series, 1198 022076, 2019. 
[5]. T. Setiadipura, T. Obara, "Development of Monte Carlo-based pebble bed reactor fuel management code", Annals of Nuclear Energy, 71, 313-321, 2014.

[6]. X. Jing, X. Xu, Y. Yang, R. Qu, "Prediction calculations and experiments for the first criticality of the 10MW High Temperature Gas-cooled Reactor-Test Module", Nucl. Eng. Des., 218, 4349, 2002.

[7]. E. Teuchert, et al., V.S.O.P('94) Computer Code System for Reactor Physics and Fuel Cycle Simulation (Juel-2897), Germany, 1994.

[8]. V. Seker, U. Colak, "HTR-10 full core first criticality analysis with MCNP", Nucl. Eng. Des., 222, 263-270, 2003.

[9]. Zuhair, Suwoto, P. Supriatna, "Studi Model Heksagonal MCNP5 dalam Perhitungan Benchmark Fisika Teras HTR-10, Jurnal Matematika \& Sains, 17(2), 61-70, 2013.

[10]. M.J. Wang, R.J. Sheu, J.J. Peir, J.H. Liang, "Criticality calculations of the HTR-10 pebble-bed reactor with SCALE6/CSAS6 and MCNP5", Ann. Nucl. Energy, 64, 1-7, 2014.

[11]. Wang, M.J., Peir, J.J., Chi, C.W., Liang, J.H., “A parametric study of fuel latticedesign for HTR-10”. Journal of Engineering for Gas Turbines and Power: Transactions of the ASME 133, 84503-84511, 2011.

[12]. Meng-Jen W., Jinn-Jer P., Der-Sheng C., JenqHorng L., "Effects of Homogeneous Geometry Models in Simulating the Fuel Balls in HTR-10", Journal of Power and Energy Systems, pp. 394-401, 2012.

[13]. Mohamed A. A., Moustafa A., Alya A. B., Hanaa A. G. and Abdel R. A. G., " Burnup analysis for HTR10 reactor core loaded with uranium and thorium oxide", Nuclear Engineering and Technology, Vol. 52, pp. 674-680, 2019.

[14]. Y. Nagaya, K. Okumura, T. Mori, W. Nakazato, "Analysis of the HTR-10 Initial Core with a Monte Carlo Code MVP", in Proceedings of PHYSOR 2004 - The Physics of Fuel Cycles and Advanced Nuclear Systems, US, 2004.

[15]. H. Chang, X. Raepsaet, F. Damian, Y. Lee, O. Koberl, X. Jing and Y. Yang. "Analysis of HTR-10 First Criticality with Monte Carlo Code Tripoli-4.3," in 2nd International Topical Meeting on HIGH TEMPERATURE REACTOR TECHNOLOGY, China, 1-10, 2004.

[16]. P. K. Romano and B. Forget, "The OpenMC Monte Carlo particle transport code," Annals of Nuclear Energy, Vol. 64, 274-281, 2013.

[17]. Kaichao S., Jarod W., Sara W. Ruimin J. Akshay J. D., Yang Z. and Lin-wen H., "Neutronics modeling and analysis of the TMSR-SF1 fuel lattice and full core with explicit fuel particle distribution and random pebble loadings", Progress in Nuclear Energy, Vol. 109, pp. 171-179, 2018.

[18]. J. L. Kloosterman and Abderrafi M. Ougouag. Computation of Dancoff Factors for Fuel Elements Incorporating Randomly Packed TRISO Particles. Idaho National Engineering and Environmental Laboratory, Idaho, 2005. doi:10.2172/911013.
[19]. W. S. Jodrey and E. M. Tory, "Computer simulation of close random packing of equal spheres", Phys. Rev. A, 32, 2347-2351, 1985.

[20]. IAEA-TECDOC-1382 Evaluation of high temperature gas cooled reactor performance: Benchmark analysis related to initial testing of the HTTR and HTR-10. International Atomic Energy Agency (IAEA), Vienna, November 2003.

[21]. Z. Wu, D. Lin and D. Zhong, "The Design Features of The HTR-10," Nucl. Eng. Des., 218, 25-32, 2002.

[22]. F.B. Brown, W.R. Martin, "Stochastic Geometry Capability in MCNP5 for the analysis of particle fuel," Annals of Nuclear Energy, 31, 2039-2047, 2004.

[23]. E.A. Sunny, G. Ilas, "Scale 6 Analysis of HTR-10 Pebble Bed Reactor for Initial Critical Configuration", in Proceeding of PHYSOR 2020 Advances in Reactor Physics to Power the Nuclear Renaissance, USA, 2010. 